\title{
Isolation of Food Pathogenic Bacteria from Unhygienic Fruit Juice Mill and Screening Various Herbal Plant Extracts for Inhibitory Potential
}

\author{
Balvindra Singh* and Neelam Singh
}

Saaii College of Medical Science and Technology Chaubepur, Kanpur UP-209203, India

*Corresponding author

\begin{abstract}
Keywords
Microbes fruit juice,

food pathogen,

Antibiotics

resistance, Plant

Extracts, Grams

Staining and

Culture

Characteristics

Article Info

Accepted:

14 December 2018

Available Online:

10 January 2019 accepted that fruit juice consumption is a risk factor for infection with enteric pathogens. The trouble begins when certain bacteria and other harmful pathogens spores of multiply and spread in ubiquitous and environments. However, fruit juice Sample was collected from the various places of Kanpur, India and observed the highest microbial load in nutrient agar $\left(4.3 \mathrm{X} 10^{7}\right)$ viz., Shivrajpur, rose bengal chloramphenicol agar $\left(2.8 \mathrm{X} 10^{7}\right)$ Viz. Chaubepur-A and MacConkey agar $\left(6.8 \times 10^{5}\right)$ viz. Chaubepur-B. Bacteria were identified as Serratia, Escherichia coli, Staphylococcus, Salmonella, Klebsiella and Proteus spp. in different types of fruit juices from the various fruit mill vendors; While, these pathogens confirmed by biochemical, Grams staining and culture methods. Prevention of food spoilage and food poisoning pathogens is usually achieved were herbal plant leaf and pulp extraction through chemical solvent method. Including, Plants are a prospective source of antimicrobial agents in India and other countries. About 60 to $90 \%$ of populations in the developing countries use plant-derived medicine. Traditionally, crude plant extracts are used as herbal medicine for the treatment of a human. While Thuja leaf analyzed were effective for the antimicrobial activity against Serratia bacteria Viz. highest $20 \mathrm{~mm}$ zone observed in Muller Hinton Agar. The study suggests that high levels of antimicrobial activity are present in herbal extracts prepared from various plant leaves that have good potential in terms of human as well as a combination of fruit juice properties, respectively.
\end{abstract}

\section{A B S T R A C T}

Microbes are the sources of many food poisoning cases, usually due to improperly processed food and fruit juice separation by hand or juice mill. It is now commonly

\section{Introduction}

Citrus products are marketed as fresh or reconstituted single strength juices and as frozen concentrates. None are sterile. Microorganisms enter in the fruit at the harvesting time, during fruit processing, packing and plant surface of the fruit having originated from the soil, the untreated surface of the water, dust and decomposing fruit etc.
The degree of contamination varies depending upon how the fruit was handled from the field and in the processing plant. Proper grading, washing and sanitizing the fruit contribute materially to good product quality. In India, chances of transmission of disease through fruit and fruit juices are due to unsatisfactory hygiene, adulteration practices and consumption of untreated juices. Untreated juice, juice that has not been exposed to heat 
or other appropriate processes (e.g., pasteurization, boiled, UV light treatment and other chemical treatment) designed to destroy microorganisms that can make people sick. Micro-organisms are present both side as well as outside and inside of fruits and vegetable cell wall. These bacteria can cause abnormal flavors and odors but they fail to grow at high sugar concentrations or low temperatures $\left(45 \%\right.$ sucrose, below $\left.5^{\circ} \mathrm{C}\right)$ characteristic of concentrates. Acetic acid bacteria, yeasts and molds are also present and can grow when the juice has held temperatures permitting their growth. Yeasts are primarily responsible for spoilage of chilled juice that is not sterile. Coliforms are rare in fruit juices. A very high occurrence of false positives result due to species of Erwinia, E. coli, Pseudomonas aeruginosa, Serratia marcescens and other coliform types associated with plants, these are not human or animal "fecal coliforms."

Never the less, coliforms have been reported to retain viability in frozen concentrates but die off rapidly in fresh or reconstituted juices. Thus, coliforms are of little or no public health significance in fresh or frozen citrus products. Even though spores of Clostridium botulinum cannot germinate or grow, this does not rule out the importance of maintaining high sanitary standards in processing plants. Further, the rapidity at which lactic acid bacteria can grow during processing requires good sanitary practice to prevent spoilage.

In recent years the increasing consumer awareness has emphasized the need for microbiologically safe food. Since the human food supply consists basically of plants and animals or products derived from them, it is undesirable that our food supply can contain microorganisms in interaction with the food (Hylemariam Mihiretie et al., 2015).

During the twentieth century, untreated juice was implicated as the cause of foodborne illness in at least 15 outbreaks in the United States. One sensational case occurred in 1996 when 70 people, including a child who died, became ill after drinking unpasteurized apple juice and cider contaminated with $E$. coli O157: H7. In another, in 1999-2000, hundreds of people in the USA and Canada were sickened and one died from consuming unpasteurized orange juice contaminated with salmonella. When the micro-organisms involved are pathogenic, their association with our food is critical from a public health point of view. Serious health hazards due to the presence of pathogenic microbes in food can lead to food poisoning outbreaks.

Contaminated fruit juices may cause infections or irritations of the gastrointestinal (GI) tract caused by harmful bacteria, parasites, viruses, or chemicals like pesticide. Common symptoms of juice borne illnesses include vomiting, diarrhea, abdominal pain, fever, and chills.

Mainly Salmonella, Campylobacter jejuni (C. jejuni), Shigella, Escherichia coli (E. coli), are present in unhygienic fruit juices which include several different strains. Common sources of $E$. coli are unpasteurized fruit juices and freshly produced juice. Listeria monocytogenes (L. monocytogenes), Vibrio, Clostridium botulinum may also be found occasionally (Scallan et al., 2011).

At the time of consumptions, the majorities of bacteria found on the surface are usually Gram-negative and belong to the Enterobacteriaceae. Many of those organisms are usually nonpathogenic to humans. The inner tissues of fruits are usually regarded as sterile. However, bacteria can be present in low number as a result of the uptake of water through certain irrigation or washing procedures (Bagde and Tumane et al., 2011). The low $\mathrm{pH}$ of fruit juices greatly limits the number of bacteria that can survive or grow. Lemon or lime juice is $\mathrm{pH} 2.2$ to 2.6 and none 
of the normal spoilage bacteria can grow or survive that low $\mathrm{pH}$. Orange juice is $\mathrm{pH} 3.4$ to 4.0 and Lactobacillus spp. and Leuconostoc spp. can survive and grow under these conditions (Kamal Rai aneja et al., 2014).

\section{Enumeration of pathogens in fruit juice}

MPN (Most probable number)presumptive test

To $50 \mathrm{ml}$ of juice sample, $450 \mathrm{ml}$ of Butterfield's phosphate-buffered water was added and blended for $2 \mathrm{~min}$. If $<50 \mathrm{ml}$ of the samples available, the portion that is equivalent to half of the sample is used and sufficient volume of sterile diluents is added to make a 1:10 dilution. Prepare decimal dilutions with sterile Butterfield's phosphate diluent or equivalent. A number of dilutions to be prepared depend on anticipated coliform density. Shake all suspensions 25 times in 30 $\mathrm{cm}$ vortex mix for 10 seconds. Using at least 3 consecutive dilutions, inoculate $1 \mathrm{ml}$ aliquots from each dilution into 3 LST tubes for a 3 tube MPN analysis (other analysis may require the use of 5 tubes for each dilution). Lactose Broth may also be used. For better accuracy, use a $1 \mathrm{ml}$ or $5 \mathrm{ml}$ pipet for inoculation. Do not use pipets to deliver $<10 \%$ of their total volume; e.g. a $10 \mathrm{~mL}$ pipet to deliver $0.5 \mathrm{ml}$. Hold pipet at an angle so that its lower edge rests against the tube. Not more than 15 min should elapse from the time the sample is blended until all dilutions are inoculated in appropriate media. Incubate $\mathrm{LST}$ tubes at $35^{\circ} \mathrm{C} \pm 0.5^{\circ} \mathrm{C}$.

Examine tubes and record reactions at $24 \pm 2$ $h$ for gas, i.e., displacement of the medium in fermentation vial or effervescence when tubes are gently agitated. Re-incubate gas-negative tubes for an additional $24 \mathrm{~h}$ and examine and record reactions again at $48 \pm 3 \mathrm{~h}$. The confirmed test was performed on all presumptive positive (gas) tubes.

\section{MPN- confirmed test}

Lactose broth tube from the Presumptive test, transfer a loopful of each suspension to a tube of EC broth (a sterile wooden applicator stick may also be used for these transfers). Incubate EC tubes $24 \pm 2 \mathrm{~h}$ at $45.5{ }^{\circ} \mathrm{C}$ and examine for gas production. If negative, re-incubated and examine again at $48 \pm 2 \mathrm{~h}$. Use the results of this test to calculate fecal coliform MPN. To continue with E. coli analysis, proceed to Section F below. The EC broth MPN method may be used for seawater and shellfish since it conforms to recommended procedures.

Note: Fecal coliform analyses are done at $45.5 \pm 0.2^{\circ} \mathrm{C}$ for all foods, except for water testing and in shellfish and shellfish harvest water analysis, which uses an incubation temperature of $44.5 \pm 0.2^{\circ} \mathrm{C}$.

\section{MPN- completed test}

To perform the completed test for E. coli, gently agitate each gassing EC tube, remove a loopful of broth and streak for isolation on an L-EMB agar plate and incubate for 18-24 h at $35^{\circ} \mathrm{C} \pm 0.5^{\circ} \mathrm{C}$. Examine plates for suspicious $E$. coli colonies, i.e., dark centered and flat, with or without a metallic sheen.

5 suspicious colonies were transferred from each L-EMB plate to PCA slants, incubated for $18-24 \mathrm{~h}$ at $35^{\circ} \mathrm{C} \pm 0.5^{\circ} \mathrm{C}$ and use for further testing.

Note: Identification of any 1 of the 5 colonies as $E$. coli is sufficient to regard that EC tube as positive; hence, not all 5 isolates may need to be tested.

Gram stain was performed. All cultures appearing as Gram-negative, short rods should be tested for the IMViC reactions below and also re-inoculated back into LST to confirm gas production (a Combined compendium of food additive specification 
book 2005).

\section{Indole production}

Tube of tryptone broth was inoculated and incubated for $24 \pm 2 \mathrm{~h}$ at $35^{\circ} \mathrm{C} \pm 0.5^{\circ} \mathrm{C}$. Test for indole by adding 0.2-0.3 ml of Kovacs' reagent. The appearance of a distinct red color in the upper layer is a positive test.

\section{Voges-Proskauer (VP)}

Tube of MR-VP broth was inoculated and incubated for $48 \pm 2 \mathrm{~h}$ at $35^{\circ} \mathrm{C} \pm 0.5^{\circ} \mathrm{C}$. Transfer $1 \mathrm{ml}$ to $13 \times 100 \mathrm{~mm}$ tube. Add 0.6 $\mathrm{ml}$ naphthol solution and $0.2 \mathrm{ml} 40 \% \mathrm{KOH}$, and shake. Add a few crystals of creatine. Shake and let stand 2-hour test is positive if eosin pink color develops.

\section{Methyl red}

Reactive compounds. After VP test, incubated MR-VP tube additional $48 \pm 2$ hours at $35^{\circ} \mathrm{C} \pm$ $0.5^{\circ} \mathrm{C}$. 5 drops of methyl red solution was added to each tube. The distinct red color is a positive test. Yellow is a negative reaction.

\section{Citrate}

Lightly inoculates a tube of Koser's citrate broth; avoid detectable turbidity. Incubate for 96 hours at $35^{\circ} \mathrm{C} \pm 0.5^{\circ} \mathrm{C}$. Development of distinct turbidity is a positive reaction. Gas from lactose, inoculate a tube of LST and incubate $48 \pm 2$ hours at $35^{\circ} \mathrm{C} \pm 0.5^{\circ} \mathrm{C}$. Gas production (displacement of the medium from the inner vial) or effervescence after gentle agitation is a positive reaction.

\section{Interpretation}

All cultures that (a) ferment lactose with gas production within 48 hours at $35^{\circ} \mathrm{C}$, (b) appear as Gram-negative nonspore-forming rods and (c) give IMViC patterns of ++-(biotype 1) or -+-- (biotype 2) are considered to be E. coli. Calculate MPN (see Appendix 2) of E. coli based on the proportion of EC tubes in 3 successive dilutions that contain $E$. coli.

Note: Alternatively, instead of performing the IMViC test, use API20E or the automated VITEK biochemical assay to identify the organism like E. coli. Use growth from the PCA slants and perform these assays as described by the manufacturer.

\section{Solid medium method- coliforms}

Prepare violet red bile agar (VRBA) according to manufacturer's instructions. Cool to $48^{\circ} \mathrm{C}$ before use. Prepare, homogenize, and decimally dilute sample as described in section I. C above so that isolated colonies will be obtained when plated. Transfer two 1 $\mathrm{ml}$ aliquots of each dilution to Petri dishes, and use either of the following two pour plating methods, depending on whether injured or stressed cells are suspected to be present.

Pour $10 \mathrm{ml}$ VRBA tempered to $48^{\circ} \mathrm{C}$ into plates, swirl plates to mix, and let solidify. To prevent surface growth and spreading of colonies, overlay with $5 \mathrm{ml}$ VRBA and let solidify. If resuscitation is necessary, pour a basal layer of 8-10 ml of tryptic soy agar tempered to $48^{\circ} \mathrm{C}$. Swirl plates to mix, and incubate at room temperature for $2 \pm 0.5 \mathrm{~h}$. Then overlay with $8-10 \mathrm{ml}$ of melted, cooled VRBA and let solidify.

Invert solidified plates and incubates $18-24 \mathrm{~h}$ at $35^{\circ} \mathrm{C}$. Incubate dairy products at $32^{\circ} \mathrm{C}$. Examine plates under a magnifying lens and with illumination. Count purple-red colonies that are $0.5 \mathrm{~mm}$ or larger in diameter and surrounded by a zone of precipitated bile acids. Plates should have 25-250 colonies. To confirm that the colonies are coliforms, pick at least 10 representative colonies and transfer each to a tube of BGLB broth. Incubate tubes 
at $35^{\circ} \mathrm{C}$. Examine at 24 and $48 \mathrm{~h}$ for gas production.

Note: If gas-positive BGLB tube shows a pellicle, perform Gram stain to ensure that gas production was not due to Gram-positive, lactose-fermenting bacilli. Determine the number of Co-Food homogenates will easily clog filters, hence MF are most suitable for analysis of water samples; however, MF may be used in the analysis of liquid foods that do not contain high levels of particulate matter such as bottled water (see Section III for application of MF) coliforms per gram by multiplying the number of suspect colonies by percent confirmed in BGLB by dilution factor.

Alternatively, E. coli colonies can be distinguished among the coliform colonies on VRBA by adding $100 \mu \mathrm{g}$ of 4-methylumbelliferyl-D-glucuronide (MUG) per $\mathrm{ml}$ in the VRBA overlay. After incubation, observe for bluish fluorescence around colonies under long wave UV light (see LST-MUG section II for theory and applicability).

\section{Membrane filtration method}

Food homogenates will easily clog filters, hence MF is most suitable for analysis of water samples; however, MF may be used in the analysis of liquid foods that do not contain high levels of particulate matter such as bottled water.

\section{Co-relationship of microbes and fruit juice}

Fruit juices are rich in sugars and inorganic salts are prone to contamination by ubiquity microbes. Some osmophilic bacteria live in high concentration of sugar like sugarcane juice.

Some of the microbes present in fruit juice like coliform, include E. coli, Salmonella sp., Klebsiella sp., Serratia marcescens, Proteus $s p$. and potent human pathogens etc. Since drug resistance is at a rise in these pathogens these are a constant search for herbal alternatives with high inhibitory activity and fewer side effects.

Plant extracts have less known side effects. Therefore, this paper studied the inhibitory action of various plant extracts prepared in different solvents.

\section{Materials and Methods}

Isolation of bacteria from present in various sample of fruit juice, those juice samples collected from different places.

To enumerate total plate count (TPC), Total Coliform Number and count of CFU/ml in samples.

To observe the antibiotic resistance using streptomycin, penicillin $\mathrm{G}$.

To observe the antimicrobial activities of Limonia acidissima (Kaitha), Thuja, Guava and radish plant leaf, fruit pulp and fruit seed extract against isolated bacterial (potential pathogens)

Sample collection: The samples were collected in a sterile $150 \mathrm{ml}$ uricol bottle from fruit vendors of 5 localities viz. Chaubepur (a) and (b), Shivrajpur, Kalyanpur, Kanpur Central Railway station platform No. 06.

Bacterial count for enumeration of potential pathogens: Total bacterial count (TBC) and total coliform count (TCC) was done as follows:

Total bacterial count: Total Bacteria count was done on Nutrient Agar and Colony Forming Units per $\mathrm{ml}(\mathrm{CFU} / \mathrm{ml})$ were calculated. $100 \mu \mathrm{l}$ each of undiluted, $10^{-4}$ and $10^{-5}$ were separate on nutrient agar plates. 
Total coliform count: It was carried out by spreading the juice sample $(100 \mu \mathrm{l})$ on $\mathrm{RBCa}$ medium.

\section{Purification and maintenance}

It was done by repeated sub-culturing on agar medium plate. The colonies streaked in McConkey agar plates and nutrient agar plates incubated at $37^{\circ} \mathrm{Cfor} 24$ hours in order to obtain isolated colonies of pure culture. Sub-culturing of purified colonies was also done on nutrient agar plate every seven days

\section{Identification of bacteria isolated from fruit juice}

\section{Gram staining}

Gram-positive bacteria have a thick mesh-like cell wall made of peptidoglycan (50-90\% of cell envelope), and as a result are stained purple by crystal violet, whereas gramnegative bacteria have a thinner layer (10\% of cell envelope), so do not retain the purple stain and are counter-stained pink or red colour by the Safranin. There are four basic steps of the Gram stain:

Prepare the smear in a glass slide, heat-fixed the smear of a bacterial culture. Heat fixing kills some bacteria but is mostly used to affix the bacteria in the glass slide so that they don't rinse out during the staining procedure. Then applied a primary stain (crystal violet) and wait for the 1 mints

The addition of grams iodine apply for 30 second, which binds to crystal violet and traps it in the cell,

Rapid flood decolorization with $90 \%$ alcohol or acetone and wait for 30 seconds.

Counterstaining with safranin. Corbol fusion is sometimes substituted for safranin since it more intensely stains anaerobic bacteria, but it is less commonly used as a counterstain.

\section{Biochemical tests}

\section{O/F growth on Hugh Leifson medium}

Hugh Leifson Medium is used for detecting the aerobic and anaerobic breakdown of glucose.

Formula adjusted, standardized to suit performance parameters

Note: In an additional set of tubes $5 \mathrm{~mm}$ paraffin oil may be layered on the surface of the medium for the differentiation of oxidative $\&$ fermentative organisms.

\section{Methyl Red test (MR test)}

Clark and Lumps used found that ferments glucose by producing mixed acids (e.g lactic, acetic and formic acid) which can be made visible with the addition of methyl red. These acids give a $\mathrm{pH}$ below 4.4 which means methyl red turns to red (yellow when $\mathrm{pH}>$ 5.1).

Add about 5-6 drops of the Methyl Red Solution (Fluka 08714) per $5 \mathrm{ml}$ culture. Incubate $24-48$ hours at $37^{\circ} \mathrm{C}$ and observe the color of the medium - if the $\mathrm{pH}$ falls below 4.4 the indicator change to red. In case the result is doubtful the assay must be repeated incubating at $30^{\circ} \mathrm{C}$ for 5 days.

\section{Voges-Proskauer test (VP test)}

Voges-Proskauer found a test to detect acetone and 2,3-butanediol produced due to the fermentation of glucose. They found that under alkaline conditions these two compounds oxidize themselves to diacetyl. Diacetyl reacts with creatine (a guanidine derivative) to a red or with naphtol to a violet compound. 


\section{Antibiotic resistance}

It was done as per National Council for Clinical and Laboratory Standard (NCCLS) Protocols by the disc diffusion method. The test culture suspension was prepared in $5 \mathrm{ml}$ normal saline $(0.89 \% \mathrm{NaCl})$ and $100 \mu \mathrm{l}$ was spread on Muller Hinton agar plate with a sterile glass spreader. A disc of antibiotic was kept carefully on the center of the lown using a flamed forceps.

The plate was incubated at $37^{\circ} \mathrm{C} 16$ 24hoursand the zone of inhibition was measured in $\mathrm{mm}$. This was compared with the standard values given in the NCCLS chart. If the zone was found to be greater than the mentioned values then the test culture was said to be sensitive otherwise resistant on intermediate.

\section{Antimicrobial activity of plant extracts: preparation of extracts}

Four plants thuja (orientalis), guava (Psidiumguajava) and Radish -Raphanus sativus Limonia acidissima (Kaitha) were selected. Leaf extract was prepared in one polar and one nonpolar solvent. The polar solvent used was ethanol and nonpolar solvent being directly either. Procedure $-5 \mathrm{~g}$ leaf tissue was crushed in a sterile mortar with a sterile pestle using $10 \mathrm{ml}$ of solvent at a time. The filtrate was collected in a fresh glass test tube and final volume of extract was made up to $05 \mathrm{ml}$. Testing for the antimicrobial potential of plant leaf extracts.

The 41 No. Whatman filter paper disc (presterilized) was dipped in the plant extract to be tested -allowed to dry for 5minutes inside the laminar flow keeping on the lid of a sterile Petri plate. Then this was kept on the lawn of bacterial culture prepared on Muller Hinton agar and plate were incubate at $37^{\circ} \mathrm{C}$ for 24 hours The zone of inhibition was measured in the same way as with the antibiotics mentioned in the section above.

\section{Results and Discussion}

\section{Bacterial count for enumeration of potential pathogens}

The total bacterial count (TBC), as well as total coliform count (TCC) of all five samples of juices on the Nutrient Agar, Rose Bengal chloramphenicol Agar and MacConkey Agar, were determined. The values are listed in tables 1, 2 and 3given below.

\section{Purification and maintenance}

The various morphologically 12 different colonies isolated from the vendor of fruit juice mill samples, bacteria culture were isolated then purified and maintained by repeated streaking on nutrient agar plates. Subculturing was done once in a week and once grown culture inoculation glycerol stock solution (70\%) and culture was stored at $4^{\circ} \mathrm{C}$.

\section{Identification of the potential pathogens}

The isolated cultures were subjected to gram staining. Eight out of twelve isolates were Gram-negative and four were Gram-positive. On the basis of Biochemical tests, eight of them were identified as pathogenic or potentially pathogenic. The microbes listed are given below table No. 4 .

\section{Antibiotic sensitivity}

All the isolates were sensitive to Streptomycin and Penicillin. No drugresistant or Multidrug-resistant strain could be isolated from the mill fruit juice samples. 
Table.1 Samples, media and antibiotics used in this study

\begin{tabular}{|l|l|l|l|l|}
\hline S. No. & Using medium & Chemicals & Extracts & Antibiotics \\
\hline $\mathbf{1}$ & Nutrient agar & $\begin{array}{l}\text { Diethyl } \\
\text { ether }\end{array}$ & $\begin{array}{l}\text { Thuja Orientalis } \\
\text { (Arborvitae)leaf }\end{array}$ & Penicillin-G \\
\hline $\mathbf{2}$ & Eosin Methylene Blue Agar & Ethanol & $\begin{array}{l}\text { Guava } \\
\text { (Psidiumguajava)l } \\
\text { eaf }\end{array}$ & Amoxicillin \\
\hline $\mathbf{3}$ & Muller Hinton Agar & Methanol & $\begin{array}{l}\text { Kaitha-(Limonia } \\
\text { acidissima) pulp }\end{array}$ & Ciprofloxacin \\
\hline $\mathbf{4}$ & Hugh Leafson Agar & hexane & $\begin{array}{l}\text { Radish (Raphanus } \\
\text { sativus) seed }\end{array}$ & Norfloxacin \\
\hline $\mathbf{5}$ & MacConkey Agar & Acetone & $\begin{array}{l}\text { Castor (Ricinus } \\
\text { communis) }\end{array}$ & \\
\hline $\mathbf{6}$ & $\begin{array}{l}\text { Rose Bengal chloramphenicol } \\
\text { Agar }\end{array}$ & Chlorofom & & \\
\hline
\end{tabular}

Table.1A Outbreaks of foodborne illness caused by pathogenic bacteria associated with fresh fruits

\begin{tabular}{|c|c|c|c|c|c|}
\hline S.No. & Causal agent & Year & Fruits & Cases & Place(death) \\
\hline 1 & E. coli $\mathrm{O} 157: \mathrm{H} 7$ & 2005 & Fruit salad & 18 & Home \\
\hline 2 & $\begin{array}{l}\text { Salmonella ser. } \\
\text { Braenderup }\end{array}$ & 2005 & Roma tomatoes & 84 & Restaurant \\
\hline 3 & $\begin{array}{l}\text { Salmonella } \\
\text { Braenderup }\end{array}$ & 2004 & Roma tomatoes & 137 & $\begin{array}{l}\text { Restaurant or } \\
\text { home }\end{array}$ \\
\hline 4 & $\begin{array}{l}\text { Salmonella } \\
\text { multiserotypes }\end{array}$ & 2004 & Roma tomatoes & 429 & - \\
\hline 5 & Salmonella spp. & 2003 & Strawberry & 13 & - \\
\hline 6 & $\begin{array}{l}\text { Salmonella ser. } \\
\text { Muenchen }\end{array}$ & 2003 & $\begin{array}{l}\text { Cantaloupe, } \\
\text { Honeydew melons }\end{array}$ & 58 & - \\
\hline 7 & Salmonella ser. & 2003 & $\begin{array}{l}\text { Newport Honeydew } \\
\text { melons }\end{array}$ & 68 & - \\
\hline 8 & Salmonella ser. Berta & 2002 & Watermelon & 29 & - \\
\hline 9 & $\begin{array}{l}\text { Salmonella ser. } \\
\text { Poona }\end{array}$ & 2002 & Cantaloupe melon & 26 & - \\
\hline 10 & $\begin{array}{l}\text { Salmonella } \\
\text { Newport }\end{array}$ & 2002 & Tomatoes & 510 & \\
\hline 11 & $\begin{array}{l}\text { Salmonella } \\
\text { Poona }\end{array}$ & 2001 & $\begin{array}{l}\text { Honeydew melons, } \\
\text { watermelon }\end{array}$ & 23 & Restaurant \\
\hline 12 & $\begin{array}{l}\text { Salmonella } \\
\text { Enteritidis }\end{array}$ & 1999 & $\begin{array}{l}\text { Honey dew } \\
\text { melons/watermelon }\end{array}$ & 82 & School \\
\hline 13 & $\begin{array}{l}\text { Salmonella } \\
\text { Newport }\end{array}$ & 1999 & Mango & 79 & Multiple \\
\hline 14 & $\begin{array}{l}\text { Salmonella } \\
\text { Oranienburg }\end{array}$ & 1998 & Cantaloupe & 22 & Various \\
\hline 15 & E. coli $\mathrm{O} 157: \mathrm{H} 7$ & 1997 & Melon & 9 & Private home \\
\hline
\end{tabular}


Table.1C Viable Count of colony present in different juice samples on Nutrient agar (CFU/ml)

\begin{tabular}{|c|l|c|c|}
\hline S.NO & \multicolumn{1}{|c|}{ Sample } & No.of bacterial colony & CFU/ml $\left(\mathbf{D} / \mathbf{F}=\mathbf{1 0}^{\mathbf{5}}\right)$ \\
\hline $\mathbf{1}$ & Chaubepur (A) [Rodside] & 300 colonies & $300 \mathrm{X} 10^{5}=3 \mathrm{X} 10^{7}$ \\
\hline $\mathbf{2}$ & Chaubepur (B) [Market ] & 230 colonies & $230 \times 10^{5}=2.3 \times 10^{7}$ \\
\hline $\mathbf{3}$ & Shivrajpur, Kanpur & 430 colonies & $430 \times 10^{5}=4.3 \times 10^{7}$ \\
\hline $\mathbf{4}$ & Kalyanpur City Kanpur & 280 colonies & $280 \times 10^{5}=2.8 \times 10^{7}$ \\
\hline $\mathbf{5}$ & Kanpur Railway Station & 415 colonies & $415 \times 10^{5}=4.1 \times 10^{7}$ \\
\hline
\end{tabular}

Table.2 Viable Count of colony present in different juice samples on Rose Bengal chloramphenicol Agar (CFU/ml)

\begin{tabular}{|c|l|l|l|}
\hline S.NO & \multicolumn{1}{|c|}{ Sample } & No .of Fungus colonies & \multicolumn{1}{|c|}{ CFU/ml $\left(\mathbf{D} / \mathbf{F}=\mathbf{1 0}^{\mathbf{5}}\right)$} \\
\hline $\mathbf{1}$ & Chaubepur (A) [Rodside] & 285 colonies & $2.85 \times 10^{5}=2.8 \times 10^{7}$ \\
\hline $\mathbf{2}$ & Chaubepur (B) [Market ] & 230 colonies & $212 \times 10^{5}=2.12 \times 10^{7}$ \\
\hline $\mathbf{3}$ & Shivrajpur, Kanpur & 16 colonies & $16 \times 10^{5}=1.6 \mathrm{X} 10^{6}$ \\
\hline $\mathbf{4}$ & Kalyanpur City Kanpur & 28 colonies & $28 \times 10^{5}=2.8 \times 10^{5}$ \\
\hline $\mathbf{5}$ & Kanpur Railway Station & 201 colonies & $201 \times 10^{5}=2.0 \times 10^{7}$ \\
\hline
\end{tabular}

Table.3 Total Coliform count on MacConkey's Agar present in different juice samples $(\mathrm{CFU} / \mathrm{ml})$

\begin{tabular}{|c|l|c|c|}
\hline S.NO. & Sample & NO.of Fungus colonies & TCC/ml $\left(\mathbf{D} / \mathbf{F}=\mathbf{1 0}^{\mathbf{3}}\right)$ \\
\hline $\mathbf{1}$ & Chaubepur (A) [Rodside] & 240 & $24 \mathrm{X} 10^{3}=2.4 \mathrm{X} 10^{5}$ \\
\hline $\mathbf{2}$ & Chaubepur (B) [Market ] & 680 & $68 \times 10^{3}=6.8 \times 10^{5}$ \\
\hline $\mathbf{3}$ & Shivrajpur, Kanpur & 430 & $\mathrm{X} 10^{3}=4.3 \mathrm{X} 10^{5}$ \\
\hline $\mathbf{4}$ & Kalyanpur City Kanpur & 2 & $2 \times 10^{3}=2.9 \times 10^{3}$ \\
\hline $\mathbf{5}$ & Kanpur Railway Station & 55 & $55 \times 10^{3}=5.5 \times 10^{4}$ \\
\hline
\end{tabular}

Table.4 Gram staining pattern of isolated bacteria

\begin{tabular}{|c|c|c|c|}
\hline Culture. No & Microscopic Colour & Gram Nature & Shape of Cells \\
\hline $\mathbf{1}$ & Pink colour & Gram-negative & Short Cocci \\
\hline $\mathbf{2}$ & Pink colour & Gram-negative & Bacilli \\
\hline $\mathbf{3}$ & Voiltecolour & Gram-positive & Cocci \\
\hline $\mathbf{4}$ & Voiltecolour & Gram-positive & Cocci \\
\hline $\mathbf{5}$ & Voilte colour & Gram positive & Bacilli \\
\hline $\mathbf{6}$ & Voilte colour & Gram positive & Short Cocci \\
\hline $\mathbf{7}$ & Pink colour & Gram-negative & Bacilli \\
\hline $\mathbf{8}$ & Pink colour & Gram-negative & Cocci \\
\hline $\mathbf{9}$ & Pink colour & Gram-negative & Bacilli \\
\hline $\mathbf{1 0}$ & Pink colour & Gram-negative & Bacilli \\
\hline $\mathbf{1}$ & Pink colour & Gram-negative & Short Bacilli \\
\hline $\mathbf{1 2}$ & Pink colour & Gram-negative & Short Cocci \\
\hline
\end{tabular}


Table.5 Some biochemical tests of isolated potential pathogens from fruit juices

\begin{tabular}{|c|c|c|l|l|}
\hline S.NO. & $\begin{array}{l}\text { Methyl Red } \\
\text { (M.R.) }\end{array}$ & $\begin{array}{l}\text { Voges-Proskauer } \\
\text { test (VP) }\end{array}$ & HL medium O/F & Catalase \\
\hline $\mathbf{1}$ & Negative & positive & Facultative & Positive \\
\hline $\mathbf{2}$ & Positive & Negative & Facultative & Positive \\
\hline $\mathbf{3}$ & Positive & Positive & Facultative (gas) & Positive \\
\hline $\mathbf{4}$ & Positive & Positive & Facultative (gas) & Positive \\
\hline $\mathbf{5}$ & Negative & Positive & Facultative & Positive \\
\hline $\mathbf{6}$ & Positive & Positive & Facultative (gas) & Positive \\
\hline $\mathbf{7}$ & Positive & Negative & Oxidative & Positive \\
\hline $\mathbf{8}$ & Negative & Positive & Oxidative & Positive \\
\hline $\mathbf{9}$ & Positive & Negative & Facultative & Positive \\
\hline $\mathbf{1 0}$ & Positive & Negative & Facultative & Positive \\
\hline $\mathbf{1 1}$ & Positive & Negative & Facultative & Positive \\
\hline $\mathbf{1 2}$ & Negative & Positive & Facultative & Positive \\
\hline
\end{tabular}

Table.6 Identification of bacterial spp. by the Biochemical and culture characteristics

\begin{tabular}{|c|c|c|c|}
\hline $\begin{array}{l}\text { Culture } \\
\text { NO }\end{array}$ & $\begin{array}{l}\text { Characteristics of colonies on } \\
\text { MacConkey, MRSA and Nutrient agar }\end{array}$ & Bacterial species & Medium \\
\hline 1 & Red to pink, not mucoid and Small round & Serratia spp. & Nutrient Agar \\
\hline 2 & $\begin{array}{l}\text { Red, pink, not mucoid, round, opaque, } \\
\text { precipitation of bile salts }\end{array}$ & Escherichia coli & MacConkey’s Agar \\
\hline 3 & $\begin{array}{l}\text { Smooth, Shiny surface, Opaque and } \\
\text { pigmented golden yellow }\end{array}$ & Staphylococcus spp. & $\begin{array}{l}\text { Mannitol salt agar } \\
\text { (MSA) }\end{array}$ \\
\hline 4 & $\begin{array}{l}\text { Round, Smooth, Raised, Glistening and } \\
\text { Gray to deep golden yellow }\end{array}$ & Staphylococcus spp. & $\begin{array}{l}\text { Mannitol salt agar } \\
\text { (MSA) }\end{array}$ \\
\hline 5 & $\begin{array}{l}\text { Large, whitish, Granular, irregular, edge } \\
\text { and Margins }\end{array}$ & Bacillus spp. & Nutrient Agar \\
\hline 6 & $\begin{array}{l}\text { Yellowish Colour, Raised and appear } \\
\text { Small colony }\end{array}$ & Staphylococcus & $\begin{array}{l}\text { Mannitol salt agar } \\
\text { (MSA) }\end{array}$ \\
\hline 7 & $\begin{array}{l}\text { Circular, Colourless, transparent or amber } \\
\text { and Smooth }\end{array}$ & Salmonella spp. & Mac Conkey's Agar \\
\hline 8 & Circular, convex, Mucoid and opaque & Klebsiella sp. & MacConkey’s Agar \\
\hline 9 & $\begin{array}{l}\text { Colourless, transparent and Large colony } \\
\text { appear }\end{array}$ & Proteus spp. & Nutrient Agar \\
\hline 10 & $\begin{array}{l}\text { Colourless, transparent and smaller } \\
\text { colonies }\end{array}$ & Proteus spp. & Nutrient Agar \\
\hline 11 & $\begin{array}{l}\text { Red, round, opaque, and metallic colour } \\
\text { appear }\end{array}$ & Escherichia coli & MacConkey’s Agar \\
\hline 12 & $\begin{array}{l}\text { Dome, Mucoid, Greyish White and } \\
\text { Opaque }\end{array}$ & Klebsiella sp. & Nutrient Agar \\
\hline
\end{tabular}


Table.7 Zones of Inhibition by various plant extracts against most isolate Serratia spp

\begin{tabular}{|c|c|c|c|c|}
\hline S.NO. & Plant & Solvent & Zone of Inhibition (mm) & $\begin{array}{c}\text { Sensitive/ } \\
\text { Resistant }\end{array}$ \\
\hline $\mathbf{1}$ & Thuja (leaves) & Ethanol & $20 \mathrm{~mm}$ & $\mathrm{~S}$ \\
\hline $\mathbf{2}$ & Thuja (leaves) & Diethyl ether & $18 \mathrm{~mm}$ & $\mathrm{~S}$ \\
\hline $\mathbf{3}$ & Castor (leaves) & Ethanol & $12 \mathrm{~mm}$ & $\mathrm{~S}$ \\
\hline $\mathbf{4}$ & Castor (leaves) & Diethyl ether & $16 \mathrm{~mm}$ & $\mathrm{~S}$ \\
\hline $\mathbf{5}$ & Guava (leaves) & Ethanol & $19 \mathrm{~mm}$ & $\mathrm{~S}$ \\
\hline $\mathbf{6}$ & Guava (leaves) & Diethyl ether & $16 \mathrm{~mm}$ & $\mathrm{~S}$ \\
\hline $\mathbf{7}$ & Kaitha (fruit pulp) & Acetone & $10 \mathrm{~mm}$ & $\mathrm{~S}$ \\
\hline $\mathbf{8}$ & Kaitha (fruit pulp) & Chloroform & $08 \mathrm{~mm}$ & $\mathrm{~S}$ \\
\hline $\mathbf{9}$ & Radish (seed) & Acetone & $18 \mathrm{~mm}$ & $\mathrm{~S}$ \\
\hline $\mathbf{1 0}$ & Radish (Seed) & Chloroform & $12 \mathrm{~mm}$ & $\mathrm{~S}$ \\
\hline
\end{tabular}

Picture.1 Picture A and B on nutrient agar medium, Picture C and D on RBCa Medium and Picture E MacConkey Agar Medium show the colony
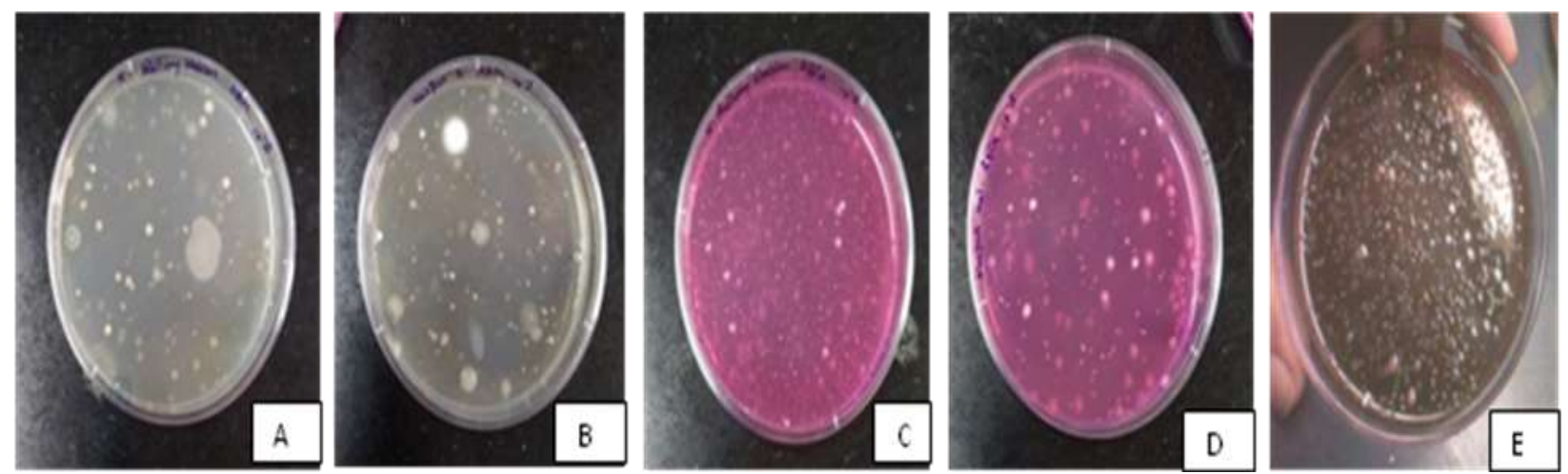

Picture.2 Pure cultures of coliforms isolated from fruit juices

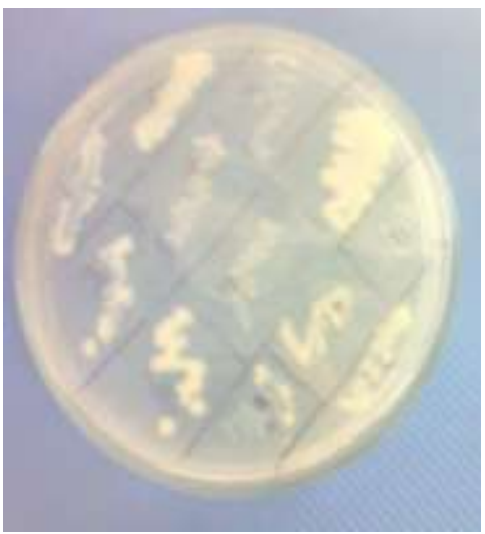


Picture.3 Gram-negative (A) and Gram-Positive (B) microscopic picture and Antibiotic sensitivity zone against isolate microbes from fruit juice (C)

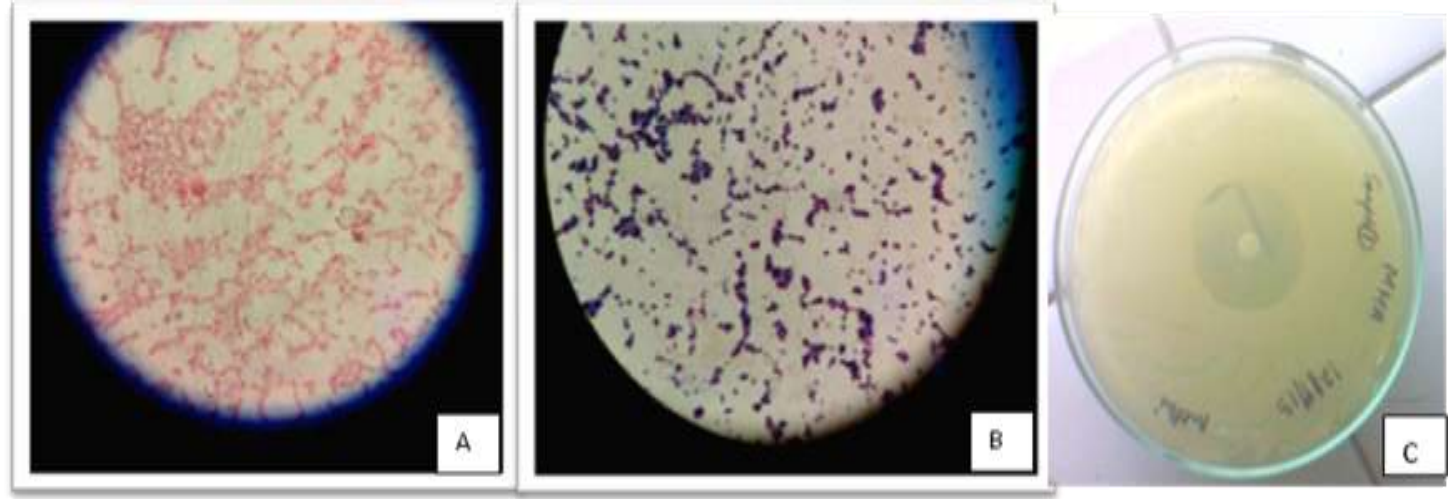

Sensitivity of Serratia spp. towards plant extracts

Serratia marcescens isolate was getting inhibited by various plant extracts.

The microbial count, as well as coliform count of most of the samples of fruit juices, was awfully (Order of $10^{5}$ to $10^{7} \mathrm{CFU} / \mathrm{ml}$ ). Definitely, these are a result of the unhygienic extraction process and mixing of tap water/ well water by the vendors in these juices. The coliforms observe in the fruit juices these come from the roadside dust and water added to them which has fecal contamination. The safe limits of coliforms in water are 1-8 coliform per $100 \mathrm{ml}$ according to WHO.

Most of the coliforms in fruit juices are reported as non-pathogenic by many authors all around the world. Various other pathogens like Salmonella spp., Klebsiella spp., Proteus spp., Serratia spp., $\quad$ S. aureus and Pseudomonas spp. were also detected which is an alarming condition for public health.

The ethanolic extract of Thuja occidentalis had a maximum inhibitory effect on the growth of S. marcescens (Throat Pathogens). This may be because of a therapeutic ingredient the nonsteroid 5 reductase inhibitors are present (Balvindra Singh et al.,
2018). Thuja polysaccharide (TPS) are known to inhibit the human immunodeficiency depend on cell death at a final concentration TPS $625 \mu \mathrm{g}$ was shown to be completely nontoxic for an MT4 cell which had not been infected with HIV-1 TPS were shown to inhibited HIV.

In conclusion our results indicated that Microbial count is too high in all the samples, they are not fit for human consumption because all type of pathogens should be found in fruit juice and it extremely harmful for the human body.

The Thuja (ethanol) extract showed the best inhibitory activity against Serratia marcescens. Therefore it can be mixed in fruit juice and Thuja extract used as a candidate like a microbial fortification.

\section{References}

Al-jedah, J.H., and Robinson R.K. 2002. Nutritional value and microbiological safety of fresh fruit juices sold through retail outlets in Qatar. Pakistan. J Nutr 1: 79-81.

Bagde N.I., and Tumane P.M. 2011. Studies on the microbial flora of fruit juices and cold drinks. Asiatic Journal of Biotechnology Resources. 2(04). 454- 
460.

Balvindra Singh., Neelam Singh, and Raghvendra singh, 2018. Isolation of Staphylococcus and gram-negative bacteria from the hospitalized area and screening bacteria against various plant extract. International Journal of Medical Science and Clinical Invention. 5(03): 3619-3624.

Brokaw, C. H., 1953. The role of sanitization in quality control of citrus concentrates. Food Engr. 25 (7). 9495.

Farmer, J.J., III. 2003. Enterobacteriaceae: introduction and identification. p. 636671.

Faville, L. W., and Hill E.C. 1952. Acid tolerant bacteria in Citrus Juice. Ibid. 17: 281-287.

Forbes, B.A., D.F. Sahm, and A.S. Weissfeld. 2002. Bailey \& Scott.s diagnostic microbiology. 11th ed. Mosby. Inc. St. Louis.

Gaithersburg, M.D., 2001. National Committee for Clinical Laboratory Standards. Approved Guideline M29A2. Protection of laboratory workers from occupationally acquired infections. 2nd ed. NCCLS. Wayne. PA.

Garner, J.S., 1996. Hospital Infection Control Practices Advisory Committee. U.S. Department of Health and Human Services. Centers for Disease Control and Prevention. Guideline for isolation precautions in hospitals Infect. Control Hospital Epidemiol. 17:53-80.

Hitchins, A., P. Feng, W. Watkins, S. Rippey, and L. Chandler, 1998. Escherichia coli and the coliform bacteria. p. 4.014.29. In FDA bacteriological analytical manual. Association of Official Analytical Chemistry International.

Lewis, Joy., E. C. Kalavati, and B. Rajanna. 2006. A case study in
Vishakhapatnam city. India. Journal of Food Safet., 8. 35-38.

MacFaddin, J.F., 1985. Media for isolationcultivation-identification-maintenance of medical bacteria. vol. I. Williams \& Wilkins, Baltimore.

Murich, Edited by Wagner H., and Horharmmer L., 1970. Published by Springer-Verlag. Berlin Heidelberg. New York. Pp. 274-289.

Murray, P.R., E.J. Baron, J.H. Jorgensen, M.A. P. faller, and R.H. Yolken (ed.). Manual of clinical microbiology. 8th ed. American Society for Microbiology. Washington. D.C.

Sofowora, A., 1993. Medicinal plants and traditional medicines in Africa. Chic Hester John. Willey \& Sons, N.Y. Pp. 2056.

Suaads, Alwakeel., and Eman Abdullah Hamed. 2008. Microbial growth and chemical analysis of Bottled fruit juices and drinks in Riyadh. Saudi Arabia Research J of Microbiology. 3. 315-325.

Trease, G. E. and Evans, W. C. 1989. A Textbook of Pharmacognosy. 13th Ed. Bailliere Tinall Ltd. London.

Tschesche, R., 1971. Advances in the chemistry of antibiotics substances from higher plants. Pharmacognosy and phytochemistry. Proceeding of the 1st International Congress.

verma, R. Singh., R.K. Tiwari, N. Srivastava, S. Verma. 2012. Antibacterial activity of extracts of Citrus. Allium and Punica against foodborne spoilage Asian J. Plant Sci. Res. 2 (4) pp. 503509.

Voravuthikunchai, S.P., T. Sririrak, S. Limsuwan, T. Supawita, T. Iida, T. Hond. 2005. Inhibitory effect of active compounds from Punica granatum pericarp on verocytotoxin production by Enterohemorrhagic Escherichia coli O157: H7. J. Health Sci. 51. pp. 
590-596.

Wall, M. E., Eddy, C. R., McClenna M. L. and M.E. Klump. 1952. Detection and estimation of steroid and sapogenins in plant tissue. Analytical Chemistry. 24: 1337-1342.

Wolford E.R. \& Berry J. A. 1948. The condition of Oranges as affecting the bacterial content of frozen juice with emphasis on the coliform organism. Food Research. 13: 172-178.

Yamamura, A., A. Murai, Takamatsu H., Watabe K., 2000. Antimicrobial effect of chemical preservatives on enterohemorrhagic Escherichia coli O157: H7. J. Health Sci. 46 pp. 204208

\section{How to cite this article:}

Balvindra Singh and Neelam Singh. 2019. Isolation of Food Pathogenic Bacteria from Unhygienic Fruit Juice Mill and Screening Various Herbal Plant Extracts for Inhibitory Potential. Int.J.Curr.Microbiol.App.Sci. 8(01): 1964-1977.

doi: https://doi.org/10.20546/ijcmas.2019.801.206 